Article

\title{
Green Synthesized ZnO Nanoparticles Mediated by Mentha Spicata Extract Induce Plant Systemic Resistance against Tobacco Mosaic Virus
}

\author{
Ahmed Abdelkhalek ${ }^{1, *}$ and Abdulaziz A. Al-Askar ${ }^{2}$ \\ 1 Plant Protection and Biomolecular Diagnosis Department, ALCRI, City of Scientific Research and \\ Technological Applications, New Borg El Arab City, Alexandria 21934, Egypt \\ 2 Botany and Microbiology Department, Faculty of Science, King Saud University, Riyadh 11451, Saudi Arabia; \\ aalaskara@ksu.edu.sa \\ * Correspondence: aabdelkhalek@srtacity.sci.eg; Tel.: +002-010-0755-6883
}

Received: 28 June 2020; Accepted: 20 July 2020; Published: 23 July 2020

\begin{abstract}
Globally, plant viral infection is one of the most difficult challenges of food security, where considerable losses in crop production occur. Nanoparticles are an effective control agent against numerous plant pathogens. However, there is limited knowledge concerning their effects against viral infection. In the present study, the green synthesis of zinc oxide nanoparticles ( $\mathrm{ZnO} N P s$ ) using aqueous leaf extract of Mentha spicata was achieved. X-ray diffraction patterns confirmed the crystalline nature of the prepared ZnO NPs. Dynamic light scattering and scanning electron microscopy analyses revealed that the resultant $\mathrm{ZnO} N P$ s were spherical in shape with a particle size ranged from 11 to $88 \mathrm{~nm}$. Fourier transmission infrared spectroscopy detected different functional groups, capping and stability agents, and showed $\mathrm{Zn}-\mathrm{O}$ bond within wavenumber of $487 \mathrm{~cm}^{-1}$. Under greenhouse conditions, the antiviral activity of biological synthesized ZnO NPs $(100 \mu \mathrm{g} / \mathrm{mL})$ against Tobacco mosaic virus (TMV) was evaluated. The double foliar application of the prepared $\mathrm{ZnO}$ NPs, $24 \mathrm{~h}$ before and $24 \mathrm{~h}$ after TMV-inoculation, was the most effective treatment that showed a $90.21 \%$ reduction of viral accumulation level and disease severity. Additionally, the transcriptional levels of PAL, PR-1 (salicylic acid marker gene), CHS, and POD genes were induced and up-regulated in all ZnO NPs treated plants. Notably, the results exhibited that aqueous extract of Mentha spicata was an effective reducing agent for the green synthesis of ZnO NPs, which showed significant antiviral activity. Finally, the detected protective and curative activity of ZnO NPs against TMV can encourage us to recommend its application for plant viral disease management. To our knowledge, this is the first study describing the antiviral activity of the green synthesized ZnO NPs.
\end{abstract}

Keywords: Mentha spicata; Zinc Oxide Nanoparticles; green synthesis; XRD; DLS; FTIR; SEM; antiviral activity; gene expression

\section{Introduction}

Plant viruses are one of the most harmful diseases that result in significant losses in crop production worldwide [1]. Among them, tobacco mosaic virus (TMV) is the most serious plant virus, responsible for tremendous losses in crop yield quality and production [2-4]. Therefore, in order to maintain sustainable agriculture and food security, plant viral diseases must be controlled. Unfortunately, synthetic chemical treatments, including pesticides, are the widespread methods used for controlling plant diseases [5]. Such methods have negative impacts on the environment and human health. Hence, the development of alternative and effective ways to suppress plant viral infection is urgently needed.

Nowadays, nanotechnology is an active field of biological sciences research [6]. It is well documented that nanoparticles (NPs) play important roles in medical applications and have successful 
impacts on human pathogen control [7]. Traditionally, NPs have been synthesized via different physical and chemical methods, such as microwave irradiation, ultrasonication, laser vaporization, solid-state thermal decomposition, hydrothermal, and Sol-gel [8-11]. Such methods require high energy, expensive equipment, and space. In addition, the absorption of some toxic chemicals on their surface making it toxic for the environment and unsuitable for biological applications [12-14]. The green biosynthesis method of NPs is a safe alternative, low cost, and eco-friendly when compared to the conventional methods $[15,16]$. Additionally, the use of nontoxic extracts as reducing and stabilizing agents is also an additive advantage [17]. Because of its contents (many bioactive molecules such as polyphenols, enzymes, polysaccharides, esters, and terpenoids), plant leaf extracts may act as reducing and stabilizing agents in the nanoparticles synthesis processes [18-21].

Mentha spicata L. (genus Mentha, family Labiatae), commonly known as spearmint, garden mint, or common mint, is frequently used as herbal tea and is considered as one of the important additive spice for many foods all over the world [22]. It is well documented that the leaves of M. spicata are still used in traditional medicine to treat gastrointestinal disorders, where its essential oils possess antimicrobial and antioxidant properties [23-25]. The major chemical constituents of mentha plants were reported as pulegone, menthone, menthol, borneol, and piperitone [26,27]. Phytochemical studies showed that phenolic, flavonoid, steroids, and terpenoid were the major components of the leaves extracts responsible for the reduction and stabilization of NPs $[25,28]$.

Recently, NPs, in a nanoscale range (1 $\mathrm{nm}$ to $100 \mathrm{~nm})$, has been integrated into plant protection, as a substitution for chemical pesticides, and disease management [29,30]. At a suitable dose, NPs have the potential to promote plant growth and inhibit pathogen infection [31]. However, their antiviral properties are still in its infancy and the corresponding mechanisms are largely unclear [32]. Many researchers reported that silver nanoparticles (Ag NPs) exhibited antiviral activities against sunhemp rosette virus (SHRV) [33], bean yellow mosaic virus (BYMV) [34], tomato mosaic virus (ToMV) and potato virus Y (PVY) [35]. They suggested that Ag NPs could bind to the virus particles and inhibit viral nucleic acid replication in the plant cell. Moreover, induction of systemic acquired resistance (SAR) and improvement releasing of reactive oxygen species (ROS), which are associate with the increase in antioxidant activity, was observed [36,37].

Many studies showed that metal oxide NPs improved plant fertilization processes, increased plant growth parameters, yield, and quality, apart from their antimicrobial properties. Among metal oxide nanoparticles, zinc oxide nanoparticles ( $\mathrm{ZnO} \mathrm{NPs}$ ) is a bio-safe material having a wide range of applications in medical, industrial, agricultural, and environmental fields [38,39]. In agriculture, utilization of ZnO NPs increased plant resistance to a broad spectrum of microbes, reduced disease severity, and enhanced crop production [37,38]. Additionally, research investigations dealing with the potential activity of ZnO NPs against plant viral disease are very limited and still under investigation. Recently, the antiviral activity of chemically synthesized ZnO NPs against TMV and PVY in the tobacco plant was reported [32]. In the present study, we aimed to green synthesize ZnO NPs using M. spicata extract. Moreover, the biologically synthesized ZnO NPs were investigated using X-ray diffraction (XRD), dynamic light scattering (DLS), scanning electron microscopy (SEM), fourier transform-infrared (FTIR) spectroscopy. Additionally, the antiviral activity and efficiency of the biosynthesized ZnO NPs in inducing SAR against TMV and its effects on plant growth parameters and the transcriptional levels of tomato-defense genes, (phenylalanine ammonia-lyase (PAL), pathogen-related protein 1 (PR-1), chalcone synthase (CHS), and peroxidase (POD), were studied. To our knowledge, this is the first report of the antiviral activity of biologically synthesized ZnO NPs against plant viral infection. 


\section{Materials and Methods}

\subsection{Plant Materials and Source of Viral Isolate}

Mentha spicata L. leaves were collected from a farm in New Borg El-Arab city, Alexandria Governorate, Egypt. Virus-free tomato seeds (Solanum lycopersicum L.) cultivar GS 12 was obtained from the Agriculture Research Center, Ministry of Agriculture, Egypt. The TMV strain KH1 (Acc\# MG264131) used in this study was previously isolated from infected tomato plants [40], and maintained continuously on Nicotiana tabacum plants under greenhouse conditions.

\subsection{Leaves Extract Preparation and Green Synthesis of Zinc Oxide Nanoparticles}

Fresh leaves of M. spicata were washed thoroughly with running tap water, to remove debris and other contaminations, washed with ultrapure Milli $Q$ water three times, and air-dried at room temperature. The dried leaves were pulverized and powdered by a sterile electric blender. The aqueous extract was prepared by adding $10 \mathrm{~g}$ of leaf powder to $100 \mathrm{~mL}$ of sterile distilled water and magnetically stirred for $2 \mathrm{~h}$ at $60^{\circ} \mathrm{C}$. The extract mixture was left to cool down at room temperature, filtered through sterile Whatman No. 1 filter paper, and finally stored at $4{ }^{\circ} \mathrm{C}$ until further analysis. A $0.2 \mathrm{M}$ aqueous solution of zinc acetate dihydrate (purity 99\%, Sigma Aldrich, Darmstadt, Germany) was prepared by dissolving $4.39 \mathrm{~g}$ of zinc acetate in $100 \mathrm{~mL}$ distilled water. Green synthesis of zinc oxide nanoparticles (ZnO NPs) was carried out by the addition of $30 \mathrm{~mL}$ of aqueous leaf extract of $M$. spicata to $70 \mathrm{~mL}$ of the freshly prepared zinc acetate solution. The reacted solution was mixed, stirred, and $\mathrm{pH}$ was adjusted to 12 by adding $3 \mathrm{M}$ sodium hydroxide resulting in a pale white aqueous suspension. After stirring for $2 \mathrm{~h}$, the pale-white ZnO NPs were precipitated and washed three times with sterile distilled water followed by ethanol wash to get rid of the impurities. A pale-white powder of ZnO NPs was obtained after drying the precipitate at $60^{\circ} \mathrm{C}$ overnight.

\subsection{Characterization of Zinc Oxide Nanoparticles}

The physical properties and morphological structures of the prepared ZnO NPs were investigated using different techniques. X-ray diffraction (XRD) analysis was carried out using XRD-7000 (Shimadzu, Kyoto, Japan) diffractometer with $\mathrm{Cu} \mathrm{K} \alpha$ radiation beam $(\lambda=0.154060 \mathrm{~nm})$, operated at $30 \mathrm{KV}$ and $30 \mathrm{~mA}$ and collected data were between $10^{\circ}$ and $80^{\circ}$ in $2 \theta$. Fourier transform infrared (FTIR) spectroscopy (FTIR-8400 S, Shimadzu, Tokyo, Japan) analysis was performed to investigate different functional groups of the prepared extract. The morphological structures and size of ZnO NPs were characterized by scanning electron microscopy (SEM) at $20 \mathrm{kV}$ (JSM-6360 LA, JEOL, Tokyo, Japan). The particle size distribution of biosynthesized ZnO NPs was determined by dynamic light scattering (DLS) with a Zetasizer Nano Z 590 (Malvern, Granta Lodge, UK) instrument at $25^{\circ} \mathrm{C}$.

\subsection{Greenhouse Experimental Design and Antiviral Activity Assay}

The $\mathrm{ZnO}$ NPs were suspended in sterile distilled water at $10 \mathrm{mg} / \mathrm{mL}$, and then diluted with sterile distilled $\mathrm{H}_{2} \mathrm{O}$ to obtain a final concentration of $100 \mu \mathrm{g} / \mathrm{mL}$. By using the half-leaf method [41,42], the antiviral activity of ZnO NPs was primary tested on Datura stramonium, as a local lesion host for $\mathrm{TMV}$, according to the inhibition percentage towards the number of local lesions. Under insect-proof greenhouse conditions, tomato seeds were surface sterilized and cultivated in plastic pots $(20 \mathrm{~cm}$ in diameter) filled with sterilized soil (clay: sand, 1:1). At 28th days post seedlings, tomato seedlings were transplanted into new pots, and one week later, two upper true leaves of each tomato plant were dusted with carborundum and mechanically inoculated with $1 \mathrm{~mL}$ of semi-purified TMV as previously described $[43,44]$. The experiment was carried out in five treatments, each treatment was comprised of five replicates, and each pot contained three tomato plants. The first treatment (T1) was mock-treated plants (control), in which tomato plants inoculated with viral inoculation buffer + foliar spraying of sterile distilled $\mathrm{H}_{2} \mathrm{O}$. The second treatment (T2) was plants inoculated with TMV (infected). The third treatment (T3) included plants treated by foliar spraying of ZnO NPs $24 \mathrm{~h}$ before inoculation of TMV. 
The fourth treatment (T4) was plants treated by foliar spraying of ZnO NPs $24 \mathrm{~h}$ after the inoculation of TMV. The fifth treatment (T5) included tomato plants treated by twice foliar spraying of ZnO NPs, $24 \mathrm{~h}$ before inoculation of TMV and $24 \mathrm{~h}$ post-inoculation. All plants were kept under greenhouse conditions, $28{ }^{\circ} \mathrm{C} / 16^{\circ} \mathrm{C}$ (day/night) and $70 \%$ relative humidity, and daily observed for the recording of symptom development. Five independent biological replicates of tomato leaves of all treatments were collected at $21 \mathrm{dpi}$ and subjected to RNA extraction.

\subsection{RNA Extraction and $q R T-P C R$ Assay}

Total plant RNA was extracted using RNeasy Mini Kit according to the manufacturer's instructions (QIAGEN, Hilden, Germany). The purity and concentration of the extracted RNA were determined using SPECTROstar Nano (BMG Labtech, Ortenberg, Germany), while the agarose gel electrophoresis technique was used to check the integrity of RNA. One $\mu \mathrm{g}$ of RNA was used to synthesize the first strand of cDNA as performed and described previously [45]. The TMV accumulation level and transcriptional changes of four tomato defense-related genes (Table 1) were investigated using the qRT-PCR technique as previously performed [46,47]. To normalize the transcript expression levels, $\beta$-actin (Table 1) was used as a reference gene [48]. Each biological treatment was performed with three technical replicates on a Rotor-Gene 6000 (QIAGEN, Germantown, AL, USA) using SYBR Green PCR Master Mix (Thermo, Applied Biosystems, Foster, CA, USA). Each reaction was comprised a $20 \mu \mathrm{L}$ containing $1 \mu \mathrm{L}$ of $10 \mathrm{pmol} / \mu \mathrm{L}$ of each primer, $10 \mu \mathrm{L}$ of $2 \times$ SYBR Green PCR Master Mix, $1 \mu \mathrm{L}$ of cDNA template, and $7 \mu \mathrm{L}$ of nuclease-free water. The relative expression level was accurately calculated according to Livak and Schmittgen [49].

Table 1. Nucleotide sequences of qRT-PCR primers used in this study.

\begin{tabular}{|c|c|c|c|}
\hline Primer Name & Abbreviation & Direction & Sequence $\left(5^{\prime}-3^{\prime}\right)$ \\
\hline Phenylalanine & \multirow{2}{*}{$P A L$} & Forward & ACGGGTTGCCATCTAATCTGACA \\
\hline Ammonia-Lyase & & Reverse & CGAGCAATAAGAAGCCATCGCAAT \\
\hline \multirow{2}{*}{$\begin{array}{l}\text { Pathogenesis Related } \\
\text { Protein-1 }\end{array}$} & \multirow{2}{*}{$P R-1$} & Forward & CCAAGACTATCTTGCGGTTC \\
\hline & & Reverse & GAACCTAAGCCACGATACCA \\
\hline \multirow{2}{*}{ Chalcone Synthase } & \multirow{2}{*}{ CHS } & Forward & CACCGTGGAGGAGTATCGTAAGGC \\
\hline & & Reverse & TGATCAACACAGTTGGAAGGCG \\
\hline \multirow{2}{*}{ Peroxidase } & \multirow{2}{*}{$P O D$} & Forward & TGGAGGTCCAACATGGCAAGTTCT \\
\hline & & Reverse & TGCCACATCTTGCCCTTCCAAATG \\
\hline \multirow{2}{*}{$\begin{array}{l}\text { Tobacco mosaic virus-Coat } \\
\text { Protein }\end{array}$} & \multirow{2}{*}{$T M V-C P$} & Forward & ACGACTGCCGAAACGTTAGA \\
\hline & & Reverse & CAAGTTGCAGGACCAGAGGT \\
\hline \multirow{2}{*}{ Beta-Actin } & \multirow{2}{*}{$\beta$-actin } & Forward & ATGCCATTCTCCGTCTTGACTTG \\
\hline & & Reverse & GAGTTGTATGTAGTCTCGTGGATT \\
\hline
\end{tabular}

\subsection{Statistical Analyses}

The relative expression values of the three replicates for each biological treatment were analyzed by one-way ANOVA in the CoStat software package. Significant differences among relative expression levels were determined according to the least significant differences (LSD) at the $p \leq 0.05$ level of probability, and standard deviations $( \pm$ SD) were shown as column bars. Compared to mock-inoculated tomato tissues, relative expression values greater than 1 were categorized as increases in gene expression (up-regulation), while values less than 1 were considered as decreases in expression levels (down-regulation). 


\section{Results and Discussion}

\subsection{X-ray Diffraction (XRD) Analysis}

The XRD pattern of the biosynthesized ZnO NPs using leaves extract of M. spicata was shown in Figure 1 . The $2 \theta$ values of $\mathrm{XRD}$ at $31.76^{\circ}, 34.44^{\circ}, 36.24^{\circ}, 47.56^{\circ}, 56.66^{\circ}, 62.90^{\circ}, 66.42^{\circ}, 67.96^{\circ}, 69.14^{\circ}$, $72.64^{\circ}$, and $76.98^{\circ}$ were assigned to (100), (002), (101), (102), (110), (103), (200), (112), (201), (004), and (202) planes, respectively. All the diffraction peaks were indexed in the ZnO wurtzite structure (JCPDS card number 01-089-1397) and agree with XRD peaks of biosynthesized ZnO NPs by M. spicata plant extract [25]. The sharp and narrow peaks indicated that the biosynthesized ZnO NPs were highly crystallized. Additionally, ZnO NPs were free of impurities where no characteristic XRD peaks other than zinc oxide peaks were observed [50,51].

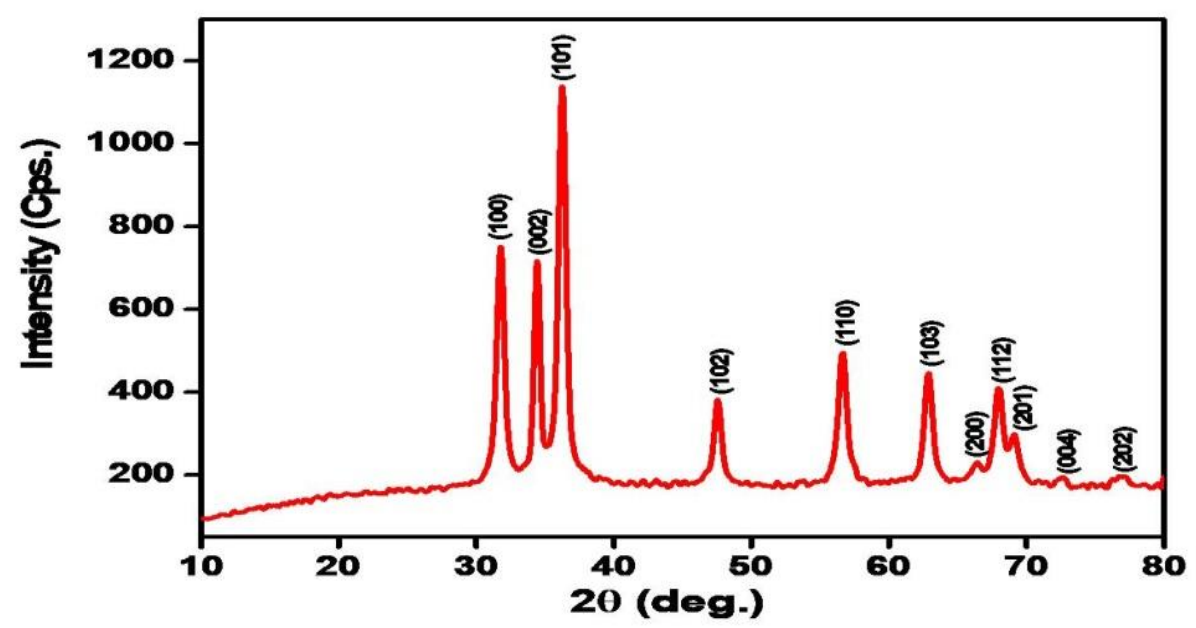

Figure 1. X-ray diffraction (XRD) patterns of zinc oxide nanoparticles biosynthesized by Mentha spicata leaf extract as reducing agents.

\subsection{FTIR Analysis}

FTIR spectroscopy was used to identify the functional groups that exist in the M. spicata extract that may act as reducing agents in the process of ZnO NPs biosynthesis. In the current study, it was found that the secondary metabolites of $M$. spicata were responsible for the reduction of zinc acetate dihydrate into ZnO NPs. The FTIR spectrum of biosynthesized ZnO NPs exhibited several peaks at 3942, 3898, 3858, 3744, 3245, 2362, 2158, 2107, 2048, 1636, 1559, 1514, 1395, 1087, 1033, 932, $840,774,714,487$, and $412 \mathrm{~cm}^{-1}$ (Figure 2). The broad peak at $3245 \mathrm{~cm}^{-1}$ indicated the presence of hydrogen-bonded groups and could be corresponded to hydroxyl groups $(\mathrm{O}-\mathrm{H})$ stretching out from the phenolic compounds that were existed in the plant extract [52-54]; likewise, the peaks at $3942-3744 \mathrm{~cm}^{-1}$ representing stretching vibration of O-H group $[55,56]$. The band at 2362 corresponded to $\mathrm{N}-\mathrm{H}$ bond of the primary and secondary amides. The peaks at 1636,1559, 1514, and $1395 \mathrm{~cm}^{-1}$ have been assigned to $C=C$ stretch of alkenes or $C=O$ stretch of amides [52,53]. The bands at 1087 and 1033 are attributed to stretching vibrations of the $\mathrm{C}-\mathrm{O}$ bond from biomolecules that existed in the leaf extract [54,56]. Additionally, peaks at 932, 840, 774 and 714 could correspond to C-N stretching amine groups [57]. The major absorption band at $487 \mathrm{~cm}^{-1}$ was allotted and characteristic to the $\mathrm{Zn}-\mathrm{O}$ bond $[25,52,56,58]$. 


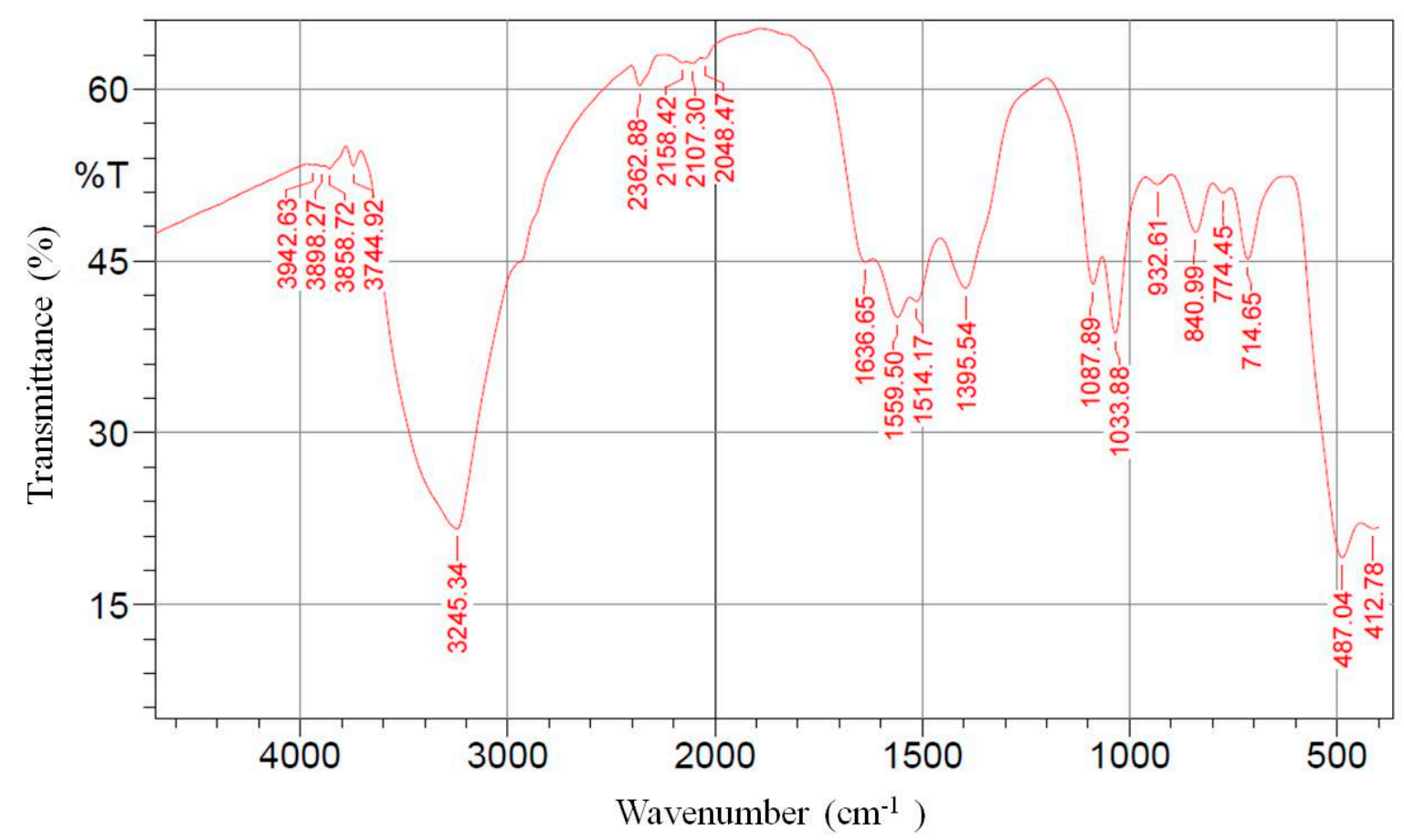

Figure 2. Fourier transform infrared (FTIR) spectra of zinc oxide nanoparticles biosynthesized by Mentha spicata leaf extract as reducing agents.

\subsection{Particle Size Distribution and Scanning Electron Microscopy Analysis}

Dynamic light scattering (DLS) is a widely used method for determining particle size distribution in a colloidal solution. In the present study, DLS analysis revealed that the average particle size of the prepared $\mathrm{ZnO}$ NPs in the aqueous medium was $74.68 \mathrm{~nm}$ (Figure 3). The surface morphology of the biosynthesized ZnO NPs was examined using scanning electron microscopy (SEM) analysis. SEM images showed that most of ZnO NPs were spherical, with some agglomerated in shape and the particle diameter range was between 11 and $80 \mathrm{~nm}$ (Figure 4). SEM analysis confirmed the morphology and size of the prepared ZnO NPs [59].

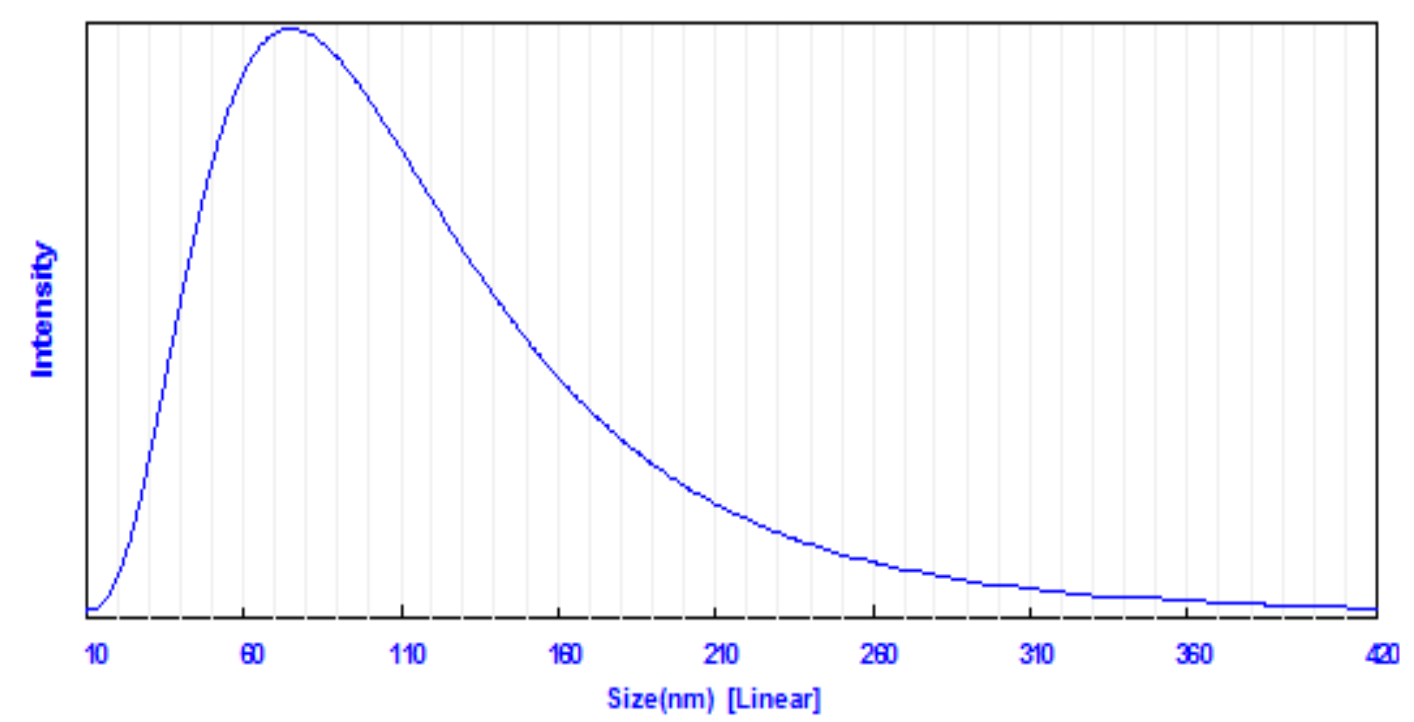

Figure 3. Particle size distribution of biosynthesized ZnO NPs using dynamic light scattering (DLS) technique. 


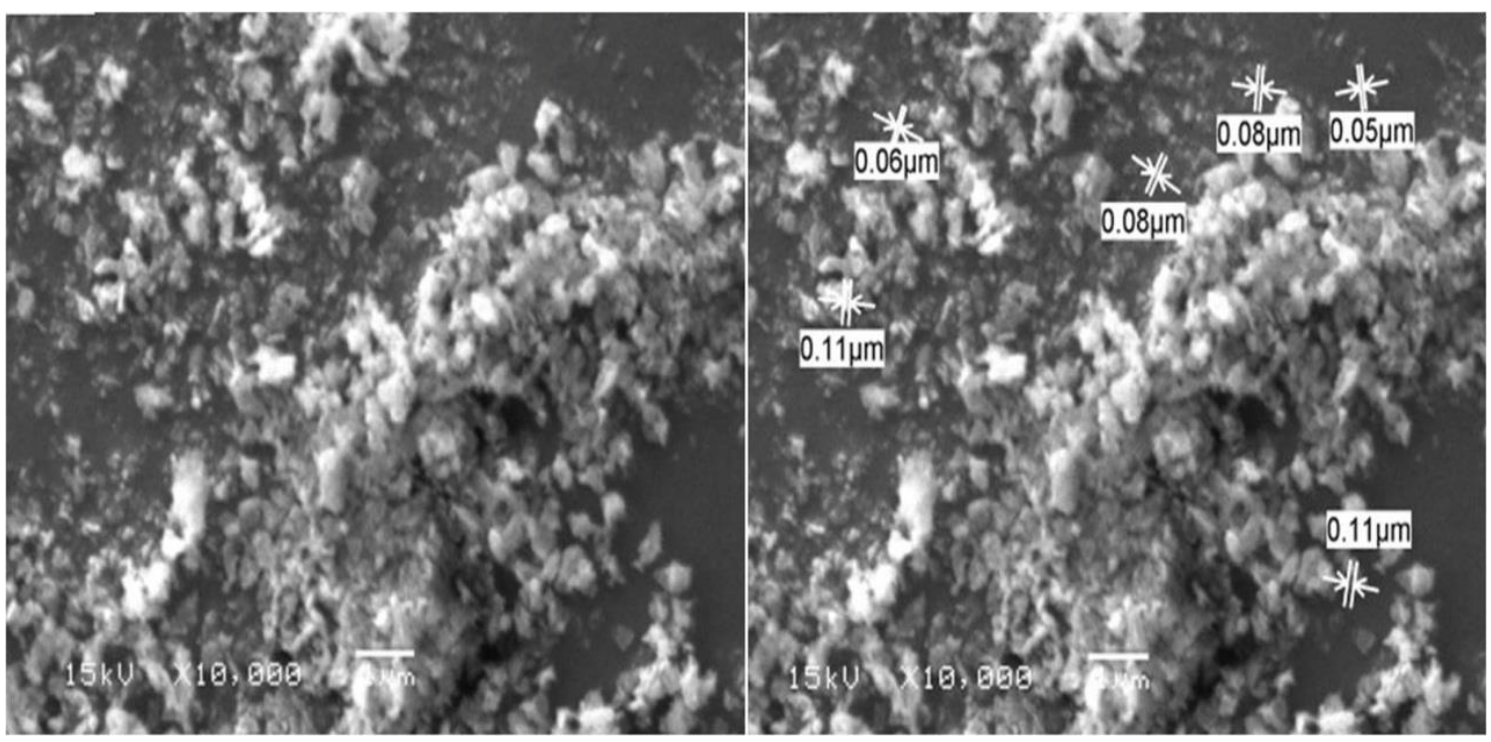

Figure 4. SEM images of zinc oxide nanoparticles biosynthesized by Mentha spicata leaf extract as reducing agents. (Bar $=1 \mu \mathrm{m}$ at $\times 10,000)$.

\subsection{Effect of Zn NPs on Disease Severity and TMV Systemic Accumulation Level}

To investigate the anti-TMV activity of the biologically prepared ZnO NPs, protective and curative assays were checked on $D$. stramonium plants by counting local lesions that were developed on the inoculated leaves. As shown in Figure 5, the number of local lesions that appeared on the right side of the treated leaves with $\mathrm{ZnO}$ NPs $(100 \mu \mathrm{g} / \mathrm{mL})$ were significantly lower than the number of lesions on the untreated left side of the leaves. The results of the protective (upper right halves of the leaves were treated with $\mathrm{ZnO}$ NPs, $24 \mathrm{~h}$ before TMV inoculation) and curative (upper right halves of the leaves were treated with $\mathrm{ZnO}$ NPs, $24 \mathrm{~h}$ after TMV inoculation) assays revealed that the biologically synthesized $\mathrm{ZnO}$ NPs show both protective and curative activities against TMV, with better protective activity (Figure 5).

Under greenhouse conditions, the foliar application of the biologically synthesized ZnO NPs $(100 \mu \mathrm{g} / \mathrm{mL})$ significantly decreased disease severity, increased plant growth, and reduced viral accumulation levels in the treated tomato plants, when compared to the infected tomato plants without treatments (T2). In the current study, at $14 \mathrm{dpi}$, the TMV-infected tomato plants (T2) showed severe mosaic symptoms similar to those reported previously [60]. On the other hand, a delayed in the development of infection symptoms for three, four, and five days was observed in $\mathrm{ZnO}$ NPs treated plants before viral inoculation (T3), ZnO NPs treated plants after viral inoculation (T5), and ZnO NPs treated plants before and after viral inoculation (T5), respectively (Figure 6). No symptoms were observed on the mock-treated plants (T1). Additionally, ZnO NPs-treated tomato plants showed a significant decrease in TMV accumulation levels in plant tissues. The qRT-PCR results exhibited that the higher accumulation level of TMV (136.60-fold) was in T2 plants, while significant decreases of accumulation level in T3 (37.14-fold), T4 (63.55-fold), and T5 (13.36-fold) plants were observed (Figure 5). The considerable reduction in TMV accumulation level in tomato leaves by $72.81 \%, 53.47 \%$, and $90.21 \%$ in T3, T4, and T5 treatments, respectively, reflected the anti-TMV activity of the biologically prepared ZnO NPs. In this context, Cai et al. [32] reported that the foliar application of the chemically prepared $\mathrm{ZnO}$ NPs decreased the accumulation level of TMV in tobacco plants and reduced disease severity [32]. Moreover, the treatment of tomato plants with Ag NPs reduced the disease severity and ToMV or PVY concentration levels inside plant tissues [35]. 


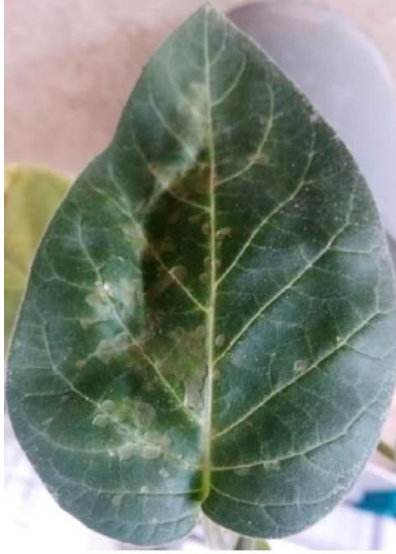

Protective treatment

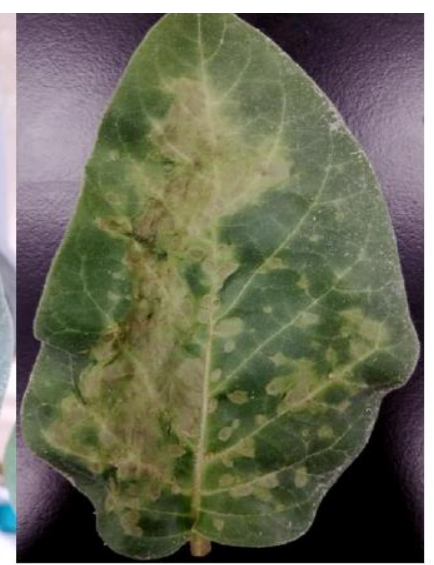

Curative treatment

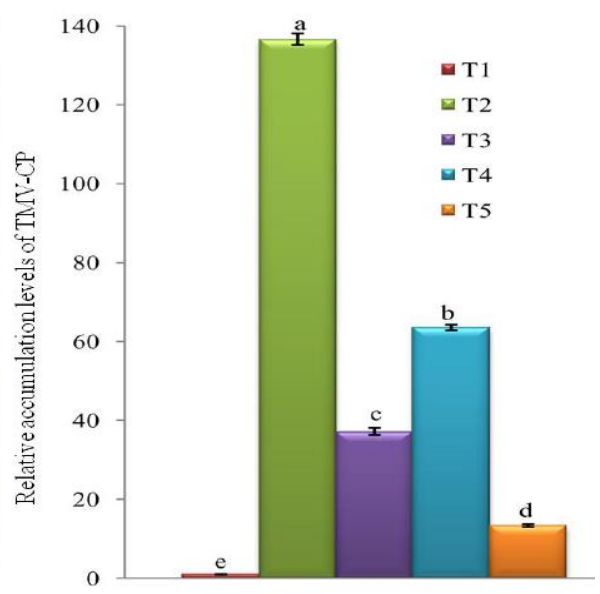

TMV-CP

Figure 5. (Left) Assay of protective and curative activities of ZnO NPs (100 $\mu \mathrm{g} / \mathrm{mL})$ against tobacco mosaic virus (TMV) on D. stramonium leaves. the half-left side of the leaves was inoculated with TMV without any treatments while the half-right side treated with ZnO NPs. (Right) A histogram showing the relative expression level of TMV-CP gene in TMV-infected tomato plants at 21 days post-inoculation. Where, T1 = Mock-treated plants (Control), T2 = plants inoculated with TMV only, T3 = plants treated with ZnO NPs (24 h before TMV inoculation), T4 = plants treated with ZnO NPs (24 h after TMV inoculation), and T5 = plant treated with ZnO NPs ( $24 \mathrm{~h}$ before TMV inoculation and $24 \mathrm{~h}$ after TMV inoculation). Columns represent mean value from three biological replicates and bars indicate standard deviation $( \pm S D)$. Significant differences between samples were determined by one-way ANOVA using CoStat software. Means were separated by least significant difference (LSD) test at $p \leq 0.05$ levels and indicated by small letters. Columns with the same letter means do not differ significantly.

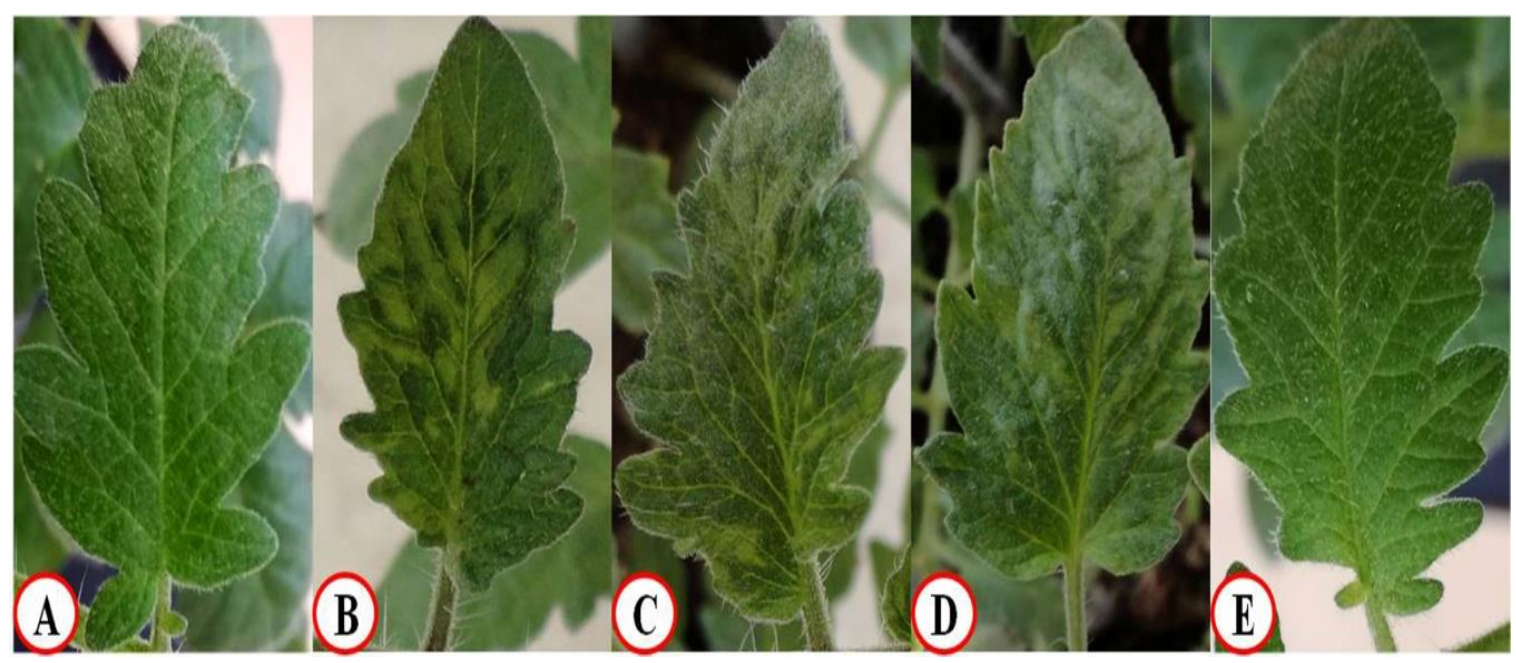

Figure 6. A photograph showing the disease symptoms on tomato leaves infected with TMV at 25 days post-inoculation. (A) mock-treated plants (T1), (B) plants inoculated with TMV only (T2), (C) plants treated with ZnO NPs $(100 \mu \mathrm{g} / \mathrm{mL}) 24 \mathrm{~h}$ before inoculation of TMV (T3), (D) plants treated with ZnO NPs $(100 \mu \mathrm{g} / \mathrm{mL}) 24 \mathrm{~h}$ after inoculation of TMV (T4), (E) plant treated with ZnO NPs $(100 \mu \mathrm{g} / \mathrm{mL}) 24 \mathrm{~h}$ before inoculation of TMV and $24 \mathrm{~h}$ after inoculation with TMV (T5).

\subsection{Transcriptional Levels of Defense-Related Genes}

At 21 dpi of all treatments, the transcription levels of four tomato-innate defense genes (PAL, PR-1, CHS, and POD) were investigated. Beside it is the first enzyme in the phenylpropanoid pathway linking the primary and secondary metabolism [61], PAL is involved in salicylic acid (SA) biosynthesis [62]. SA is an important signal that regulates systemic acquired resistance (SAR) in plants [42,63] and its 
role in plant immunity has been investigated for decades. The activation of SA, in response to pathogens, results in the accumulation and overexpression of PR-1 (SA marker gene) [64]. Compared to mock-inoculated plants (control (T1)) in the current study, a significant up-regulation of PAL with relative expression levels of 2.448-, 1.753-, and 2.590-fold change higher than control were observed in T3, T4, and T5, respectively (Figure 7). Like PAL, PR-1 expression levels in all treatments were increased with relative transcriptional levels of 1.531-, 1.375-, and 1.802-fold change in T3, T4, and T5, respectively, compared to control (Figure 7). On the contrary, PAL and PR-1 of T2 plants showed a significant down-regulation with relative expression levels of 0.064- and 0.272-fold change lower than the control treatment, respectively (Figure 7). Consequently, foliar spraying of tomato plants with the biologically synthesized ZnO NPs, either as a single treatment (before or after inoculation with TMV) or as a double treatment (before + after inoculation with TMV) triggered the expression of PAL and PR-1 genes that may cause elevated SA accumulation levels. These results suggested that the biologically synthesized ZnO NPs via M. spicata may mediate the activation of the induced systemic resistance (ISR) and can play a major role in tomato SAR against TMV infection. Many researchers reported that increased resistance against virulent pathogens was associated with an increased in PAL and PR-1 expression and elevated endogenous SA accumulation levels inside plant tissues [65-69]. The obtained results are in agreement with Cai et al. [32] who reported that upon TMV infection, chemically prepared ZnO NPs increased the expression level of the tobacco PR-1 gene that resulted in the initiation of the SA signaling pathway. In the current study, the detected down-regulation of PR-1 and PAL genes in T2 plants could be attributed to the suppressing activities of TMV against the tomato immune defense system, which resulted in a failure in the development of SAR activity.

Flavonoids, secondary metabolites, compounds play important roles in plant resistance against pathogenic microorganisms, including viruses [69-71]. Once infection occurs, flavonoids transport to the infection sites, induce hypersensitivity reactions and activate programmed cell death [72,73]. Chalcone synthase, $\mathrm{CHS}$, encodes the first enzyme of flavonoid pathway that synthesizes naringenin chalcones, is strictly needed in various plant tissues for flavonoid production [74,75]. Compared to control (T1), the transcriptional levels of CHS in treatments of T2, T3, T4, and T5 were up-regulated with relative expression levels of 1.273-, 2.38-, 1.848-, and 3.556-fold increase, respectively (Figure 7). These results showed that TMV infection slightly induced the expression of CHS in tomato tissues, while ZnO NPs treatments (T3, T4, and T5) exhibited more accumulation of CHS inside the tomato tissues. In line with the obtained results, foliar application of the biologically synthesized ZnO NPs may increase flavonoid production in plant tissues that resulted in the stimulation of the defense system against viral infection.

Reactive oxygen species (ROS) promotes programmed cell death at plant cell infection sites and plays an important role as a signaling molecule for the activation of antioxidant activity and the induction of the genes coding for pathogenesis-related proteins (PRs) [76-79]. It was reported that the increased activity of peroxidase (POD), alternative producers of ROS, was correlated with the increasing plant defense against pathogens $[78,80]$. In the current study, we observed that the application of the biologically synthesized ZnO NPs significantly increased the transcriptional levels of POD by 2.641-, 2.175-, and 3.177-fold change higher than control in T3, T4, and T5, respectively (Figure 7). Conversely, the POD of T2 plants was down-regulated with a relative expression level of 0.672-fold change lower than control (Figure 7). It was observed that the induction of POD resulted in an increase of chlorophyll content and enhanced plant resistance against mungbean yellow mosaic virus and TMV [81,82]. In addition, foliar application of Ag NPs exhibited an improvement in releasing ROS and increasing antioxidant enzymes in virally infected plant tissues [36,37]. Moreover, MgO NPs, $\mathrm{ZnO} N \mathrm{NP}$, and $\mathrm{SiO} 2 \mathrm{NPs}$ treatments induced ROS generation and suppressed TMV infection in tomato and tobacco plants [32,83]. Therefore, the foliar applications of the biosynthesized ZnO NPs may enhance SAR by releasing ROS and stimulating the expression of PR genes and SA accumulation [32]. 

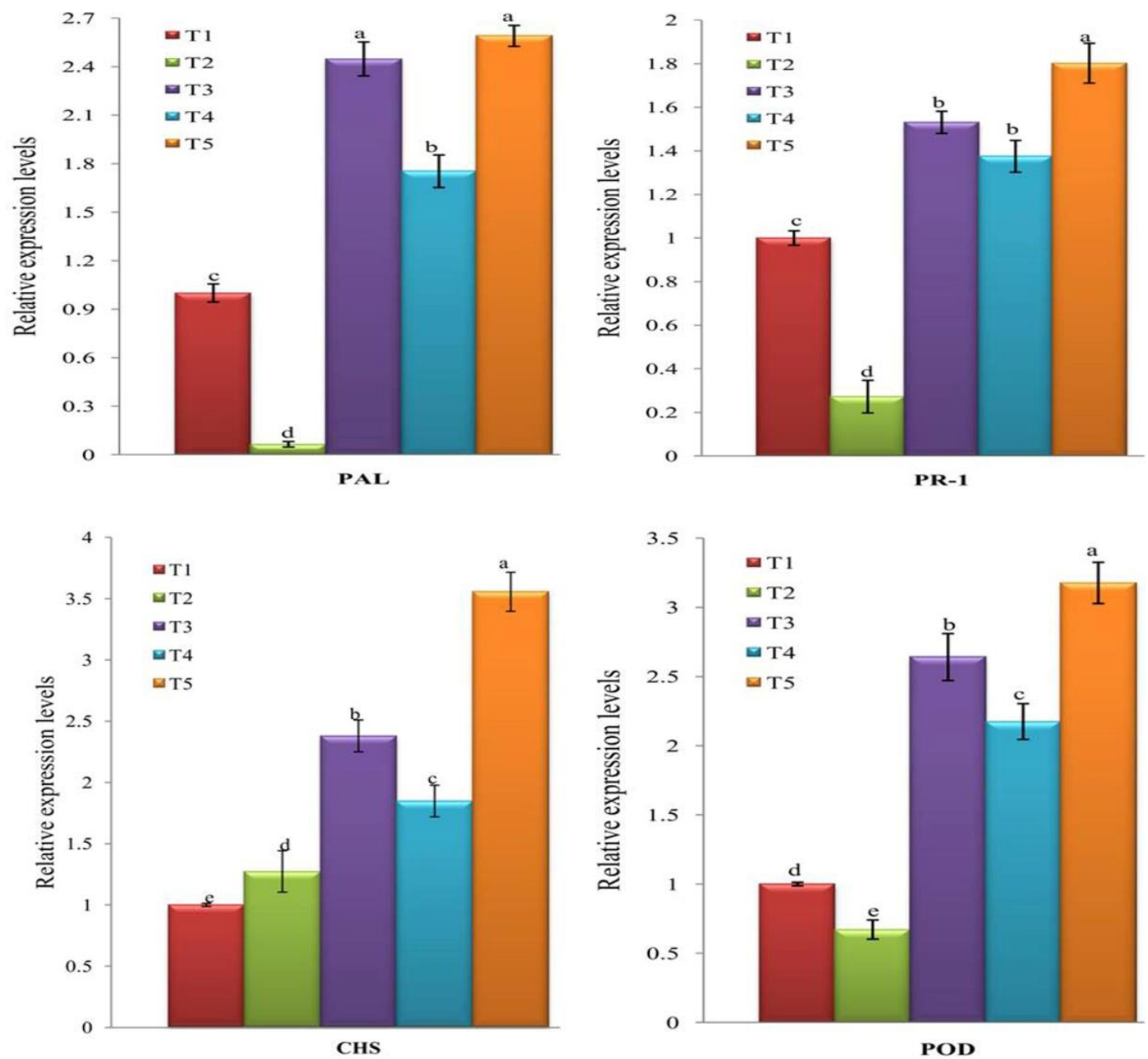

Figure 7. A histogram showing the relative expression level of PAL, PR-1, CHS, and POD in TMV-infected tomato plants at 21 days post inoculation. T1 = Mock-treated plants (Control), T2 = plants inoculated with TMV only, T3 = plants treated with ZnO NPs $(100 \mu \mathrm{g} / \mathrm{mL}) 24 \mathrm{~h}$ before inoculation of TMV, T4 = plants treated with ZnO NPs $(100 \mu \mathrm{g} / \mathrm{mL}) 24 \mathrm{~h}$ after inoculation of TMV, T5 = plant treated with ZnO NPs $(100 \mu \mathrm{g} / \mathrm{mL}) 24 \mathrm{~h}$ before inoculation of TMV and $24 \mathrm{~h}$ after inoculation with TMV. Columns represent mean value from three biological replicates and bars indicate standard deviation $( \pm \mathrm{SD})$. Significant differences between samples were determined by one-way ANOVA using CoStat software. Means were separated by least significant difference (LSD) test at $p \leq 0.05$ levels and indicated by small letters. Columns with the same letter means do not differ significantly.

\section{Conclusions}

The present investigation reported a simple, eco-friendly method for the green biosynthesis of ZnO NPs via aqueous extract of Mentha spicata leaf as a reducing and capping agent. XRD analysis confirmed the formations of ZnO NPs crystalline phases, while DLS and SEM analyses showed that $\mathrm{ZnO}$ NPs have a spherical shape and an average particle size of $74.68 \mathrm{~nm}$. Greenhouse experimental results showed that the foliar treatment of tomato plants using biologically synthesized ZnO NPs $(100 \mu \mathrm{g} / \mathrm{mL})$ induced systemic acquired resistance (SAR), decreased disease severity, reduced TMV accumulation level, increased growth parameters, and up-regulated the transcriptional levels of PAL, PR-1, CHS, and POD genes. In line with the obtained data, we suggest that the biologically prepared $\mathrm{ZnO}$ NPs have potent antiviral activity and can be applied in plant protection as elicitor molecules for the induction of SAR and plant viral disease management. 
Author Contributions: Conceptualization, A.A. and A.A.A.-A.; methodology, A.A.; software, A.A.; formal analysis, A.A.; investigation, A.A.A.-A.; writing-original draft preparation, A.A.; writing-review and editing, A.A.A.-A. All authors have read and agreed to the published version of the manuscript.

Funding: The authors extend their appreciation to the Deanship of Scientific Research at King Saud University for funding the work through the research group project No (RGP-1440-094).

Acknowledgments: The authors thank Ahmed Kenawy (GEBRI, City of Scientific Research and Technological Applications, Alexandria, Egypt) for the critical reading and revision of the manuscript.

Conflicts of Interest: The authors declare no competing interest.

\section{References}

1. Abdelkhalek, A.; Elmorsi, A.; Alshehaby, O.; Sanan-Mishra, N.; Hafez, E. Identification of genes differentially expressed in onion infected with Iris yellow spot virus. Phytopathol. Mediterr. 2018, 57, 334-340.

2. Scholthof, K.G.; Adkins, S.; Czosnek, H.; Palukaitis, P.; Jacquot, E.; Hohn, T.; Hohn, B.; Saunders, K.; Candresse, T.; Ahlquist, P. Top 10 plant viruses in molecular plant pathology. Mol. Plant Pathol. 2011, 12, 938-954. [CrossRef]

3. Bazzini, A.A.; Manacorda, C.A.; Tohge, T.; Conti, G.; Rodriguez, M.C.; Nunes-Nesi, A.; Villanueva, S.; Fernie, A.R.; Carrari, F.; Asurmendi, S. Metabolic and miRNA profiling of TMV infected plants reveals biphasic temporal changes. PLoS ONE 2011, 6, e28466. [CrossRef] [PubMed]

4. Abdelkhalek, A.; Ismail, I.A.; Dessoky, E.S.; El-Hallous, E.I.; Hafez, E. A tomato kinesin-like protein is associated with Tobacco mosaic virus infection. Biotechnol. Biotechnol. Equip. 2019, 33, 1424-1433. [CrossRef]

5. Abdelkhalek, A.; Hafez, E. Plant Viral Diseases in Egypt and Their Control. In Cottage Industry of Biocontrol Agents and Their Applications; Springer: Cham, Switzerland, 2020; pp. 403-421.

6. Fakruddin, M.; Hossain, Z.; Afroz, H. Prospects and applications of nanobiotechnology: A medical perspective. J. Nanobiotechnol. 2012, 10, 31. [CrossRef] [PubMed]

7. Zandonella, C. The tiny toolkit. Nature 2003, 423, 374. [CrossRef] [PubMed]

8. Radwan, N.R.E.; El-Shall, M.S.; Hassan, H.M.A. Synthesis and characterization of nanoparticle Co3O4, CuO and $\mathrm{NiO}$ catalysts prepared by physical and chemical methods to minimize air pollution. Appl. Catal. A Gen. 2007, 331, 8-18. [CrossRef]

9. Glaspell, G.; Hassan, H.M.A.; Elzatahry, A.; Abdalsayed, V.; El-Shall, M.S. Nanocatalysis on supported oxides for CO oxidation. Top. Catal. 2008, 47, 22-31. [CrossRef]

10. Lin, C.-C.; Li, Y.-Y. Synthesis of $\mathrm{ZnO}$ nanowires by thermal decomposition of zinc acetate dihydrate. Mater. Chem. Phys. 2009, 113, 334-337. [CrossRef]

11. Hasnidawani, J.N.; Azlina, H.N.; Norita, H.; Bonnia, N.N.; Ratim, S.; Ali, E.S. Synthesis of ZnO nanostructures using sol-gel method. Procedia Chem. 2016, 19, 211-216. [CrossRef]

12. Kharissova, O.V.; Dias, H.V.R.; Kharisov, B.I.; Pérez, B.O.; Pérez, V.M.J. The greener synthesis of nanoparticles. Trends Biotechnol. 2013, 31, 240-248. [CrossRef] [PubMed]

13. Ouda, S.M. Antifungal activity of silver and copper nanoparticles on two plant pathogens, Alternaria alternata and Botrytis cinerea. Res. J. Microbiol. 2014, 9, 34-42. [CrossRef]

14. Vanaraj, S.; Keerthana, B.B.; Preethi, K. Biosynthesis, Characterization of Silver Nanoparticles Using Quercetin from Clitoria ternateaL to Enhance Toxicity Against Bacterial Biofilm. J. Inorg. Organomet. Polym. Mater. 2017, 27, 1412-1422. [CrossRef]

15. Ansari, M.A.; Alzohairy, M.A. One-pot facile green synthesis of silver nanoparticles using seed extract of Phoenix dactylifera and their bactericidal potential against MRSA. Evid. Based Complement. Altern. Med. 2018, 2018, 1860280. [CrossRef]

16. Ali, S.G.; Ansari, M.A.; Khan, H.M.; Jalal, M.; Mahdi, A.A.; Cameotra, S.S. Antibacterial and antibiofilm potential of green synthesized silver nanoparticles against imipenem resistant clinical isolates of $P$. aeruginosa. Bionanoscience 2018, 8, 544-553. [CrossRef]

17. Zuas, O.; Hamim, N.; Sampora, Y. Bio-synthesis of silver nanoparticles using water extract of Myrmecodia pendan (Sarang Semut plant). Mater. Lett. 2014, 123, 156-159. [CrossRef]

18. Kumar, V.; Yadav, S.K. Plant-mediated synthesis of silver and gold nanoparticles and their applications. J. Chem. Technol. Biotechnol. Int. Res. Process. Environ. Clean Technol. 2009, 84, 151-157. [CrossRef] 
19. Mukunthan, K.S.; Balaji, S. Cashew apple juice (Anacardium occidentale L.) speeds up the synthesis of silver nanoparticles. Int. J. Green Nanotechnol. 2012, 4, 71-79. [CrossRef]

20. Ali, K.; Ahmed, B.; Ansari, S.M.; Saquib, Q.; Al-Khedhairy, A.A.; Dwivedi, S.; Alshaeri, M.; Khan, M.S.; Musarrat, J. Comparative in situ ROS mediated killing of bacteria with bulk analogue, Eucalyptus leaf extract (ELE)-capped and bare surface copper oxide nanoparticles. Mater. Sci. Eng. C 2019, 100, 747-758. [CrossRef]

21. Cherian, T.; Ali, K.; Fatima, S.; Saquib, Q.; Ansari, S.M.; Alwathnani, H.A.; Al-Khedhairy, A.A.; Al-Shaeri, M.; Musarrat, J. Myristica fragrans bio-active ester functionalized $\mathrm{ZnO}$ nanoparticles exhibit antibacterial and antibiofilm activities in clinical isolates. J. Microbiol. Methods 2019, 166, 105716. [CrossRef]

22. Naidu, J.R.; Ismail, R.B.; Yeng, C.; Sasidharan, S.; Kumar, P. Chemical composition and antioxidant activity of the crude methanolic extracts of Mentha spicata. J. Phytol. 2012, 4, 13-18.

23. Yousuf, P.M.H.; Noba, N.Y.; Shohel, M.; Bhattacherjee, R.; Das, B.K. Analgesic, anti-inflammatory and antipyretic effect of Mentha spicata (Spearmint). J. Pharm. Res. Int. 2013, 3, 854-864. [CrossRef]

24. Bensabah, F.; Houbairi, S.; Essahli, M.; Lamiri, A.; Naja, J. Chemical composition and inhibitory effect of the essential oil from Mentha spicata irrigated by wastewater on the corrosion of Aluminum in 1 molar hydrochloric acid. Port. Electrochim. Acta 2013, 31, 195-206. [CrossRef]

25. Rad, S.S.; Sani, A.M.; Mohseni, S. Biosynthesis, characterization and antimicrobial activities of zinc oxide nanoparticles from leaf extract of Mentha pulegium (L.). Microb. Pathog. 2019, 131, 239-245. [CrossRef] [PubMed]

26. Mikaili, P.; Mojaverrostami, S.; Moloudizargari, M.; Aghajanshakeri, S. Pharmacological and therapeutic effects of Mentha Longifolia, L. and its main constituent, menthol. Anc. Sci. Life 2013, 33, 131. [PubMed]

27. Ertaş, A.; Gören, A.C.; Haşimi, N.; Tolan, V.; Kolak, U. Evaluation of Antioxidant, Cholinesterase Inhibitory and Antimicrobial Properties of Mentha longifolia subsp. noeana and Its Secondary Metabolites. Rec. Nat. Prod. 2015, 9, 105-115.

28. Al-Bayati, F.A. Isolation and identification of antimicrobial compound from Mentha longifolia L. leaves grown wild in Iraq. Ann. Clin. Microbiol. Antimicrob. 2009, 8, 20. [CrossRef]

29. Fang, Y.; Ramasamy, R.P. Current and prospective methods for plant disease detection. Biosensors 2015, 5, 537-561. [CrossRef]

30. Elmer, W.; White, J.C. The Future of Nanotechnology in Plant Pathology. Annu. Rev. Phytopathol. 2018, 56, 111-133. [CrossRef]

31. Jha, Z.; Behar, N.; Sharma, S.N.; Chandel, G.; Sharma, D.K.; Pandey, M.P. Nanotechnology: Prospects of agricultural advancement. Nano Vis. 2011, 1, 88-100.

32. Cai, L.; Liu, C.; Fan, G.; Liu, C.; Sun, X. Preventing viral disease by ZnONPs through directly deactivating TMV and activating plant immunity in Nicotiana benthamiana. Environ. Sci. Nano 2019, 6, 3653-3669. [CrossRef]

33. Jain, D.; Kothari, S.L. Green synthesis of silver nanoparticles and their application in plant virus inhibition. J. Mycol. Plant Pathol. 2014, 44, 21-24.

34. Elbeshehy, E.K.F.; Elazzazy, A.M.; Aggelis, G. Silver nanoparticles synthesis mediated by new isolates of Bacillus spp., nanoparticle characterization and their activity against Bean Yellow Mosaic Virus and human pathogens. Front. Microbiol. 2015, 6, 453. [CrossRef] [PubMed]

35. Noha, K.; Bondok, A.M.; El-Dougdoug, K.A. Evaluation of silver nanoparticles as antiviral agent against ToMV and PVY in tomato plants. Sciences 2018, 8, 100-111.

36. Jiang, H.; Qiu, X.; Li, G.; Li, W.; Yin, L. Silver nanoparticles induced accumulation of reactive oxygen species and alteration of antioxidant systems in the aquatic plant Spirodela polyrhiza. Environ. Toxicol. Chem. 2014, 33, 1398-1405. [CrossRef]

37. Tripathi, D.K.; Singh, S.; Singh, S.; Pandey, R.; Singh, V.P.; Sharma, N.C.; Prasad, S.M.; Dubey, N.K.; Chauhan, D.K. An overview on manufactured nanoparticles in plants: Uptake, translocation, accumulation and phytotoxicity. Plant Physiol. Biochem. 2017, 110, 2-12. [CrossRef]

38. Kołodziejczak-Radzimska, A.; Jesionowski, T. Zinc oxide-From synthesis to application: A review. Materials 2014, 7, 2833-2881. [CrossRef]

39. Ali, A.; Ambreen, S.; Javed, R.; Tabassum, S.; Ul Haq, I.; Zia, M. ZnO nanostructure fabrication in different solvents transforms physio-chemical, biological and photodegradable properties. Mater. Sci. Eng. C 2017, 74, 137-145. [CrossRef] 
40. Abdelkhalek, A. Expression of tomato pathogenesis related genes in response to Tobacco mosaic virus. J. Anim. Plant Sci. 2019, 29, 1596-1602.

41. Kubo, S.; Ikeda, T.; Imaizumi, S.; Takanami, Y.; Mikami, Y. A potent plant virus inhibitor found in Mirabilis jalapa L. Jpn. J. Phytopathol. 1990, 56, 481-487. [CrossRef]

42. Abdelkhalek, A.; Salem, M.Z.M.; Ali, H.M.; Kordy, A.M.; Salem, A.Z.M.; Behiry, S.I. Antiviral, antifungal, and insecticidal activities of Eucalyptus bark extract: HPLC analysis of polyphenolic compounds. Microb. Pathog. 2020, 104383. [CrossRef] [PubMed]

43. Hafez, E.E.; Abdelkhalek, A.A.; Abd El-Wahab, A.S.E.-D.; Galal, F.H. Altered gene expression: Induction/suppression in leek elicited by Iris Yellow Spot Virus infection (IYSV) Egyptian isolate. Biotechnol. Biotechnol. Equip. 2013, 27, 4061-4068. [CrossRef]

44. Hafez, E.E.; El-Morsi, A.A.; El-Shahaby, O.A.; Abdelkhalek, A.A. Occurrence of iris yellow spot virus from onion crops in Egypt. VirusDis. 2014, 25, 455-459. [CrossRef] [PubMed]

45. Hafez, E.; El Morsi, A.A.; Abdelkhalek, A.A. Biological and molecular characterization of the fig mosaic disease. Mol. Pathog. 2011, 2, 10-17.

46. ElMorsi, A.; Abdelkhalek, A.; Alshehaby, O.; Hafez, E.E. Pathogenesis-related genes as tools for discovering the response of onion defence system against iris yellow spot virus infection. Botany 2015, 93, 735-744. [CrossRef]

47. Abdelkhalek, A.; Qari, S.H.; Hafez, E. Iris yellow spot virus-induced chloroplast malformation results in male sterility. J. Biosci. 2019, 44, 142. [CrossRef]

48. Abdelkhalek, A.; Dessoky, E.S.; Hafez, E. Polyphenolic genes expression pattern and their role in viral resistance in tomato plant infected with Tobacco mosaic virus. Biosci. Res. 2018, 15, 3349-3356.

49. Livak, K.J.; Schmittgen, T.D. Analysis of relative gene expression data using real-time quantitative PCR and the 2- $\Delta \Delta \mathrm{CT}$ method. Methods 2001, 25, 402-408. [CrossRef]

50. Bigdeli, F.; Morsali, A.; Retailleau, P. Syntheses and characterization of different zinc (II) oxide nano-structures from direct thermal decomposition of 1D coordination polymers. Polyhedron 2010, 29, 801-806. [CrossRef]

51. Kashyout, A.B.; Soliman, H.M.A.; Shokry Hassan, H.; Abousehly, A.M. Fabrication of ZnO and ZnO: Sb nanoparticles for gas sensor applications. J. Nanomater. 2010, 2010, 341841. [CrossRef]

52. Sangeetha, G.; Rajeshwari, S.; Venckatesh, R. Green synthesis of zinc oxide nanoparticles by aloe barbadensis miller leaf extract: Structure and optical properties. Mater. Res. Bull. 2011, 46, 2560-2566. [CrossRef]

53. Erci, F.; Cakir-Koc, R.; Isildak, I. Green synthesis of silver nanoparticles using Thymbra spicata L. var. spicata (zahter) aqueous leaf extract and evaluation of their morphology-dependent antibacterial and cytotoxic activity. Artif. Cells Nanomed. Biotechnol. 2018, 46, 150-158. [CrossRef] [PubMed]

54. Alamdari, S.; Sasani Ghamsari, M.; Lee, C.; Han, W.; Park, H.-H.; Tafreshi, M.J.; Afarideh, H.; Ara, M.H.M. Preparation and Characterization of Zinc Oxide Nanoparticles Using Leaf Extract of Sambucus ebulus. Appl. Sci. 2020, 10, 3620. [CrossRef]

55. Kadhem, H.S.; AL-Mathkhury, H.J.M. Inhibitory effect of menthol extracted from Mentha rubra on methicillin-resistant Staphylococcus aureus. Worl. Exp. Bioc. 2015, 3, 150-154.

56. Mohammadi-Aloucheh, R.; Habibi-Yangjeh, A.; Bayrami, A.; Latifi-Navid, S.; Asadi, A. Green synthesis of $\mathrm{ZnO}$ and $\mathrm{ZnO} / \mathrm{CuO}$ nanocomposites in Mentha longifolia leaf extract: Characterization and their application as anti-bacterial agents. J. Mater. Sci. Mater. Electron. 2018, 29, 13596-13605. [CrossRef]

57. Gupta, M.; Tomar, R.S.; Kaushik, S.; Mishra, R.K.; Sharma, D. Effective antimicrobial activity of green ZnO nano particles of Catharanthus roseus. Front. Microbiol. 2018, 9, 2030. [CrossRef]

58. Taş, A.C.; Majewski, P.J.; Aldinger, F. Chemical preparation of pure and strontium-and/or magnesium-doped lanthanum gallate powders. J. Am. Ceram. Soc. 2000, 83, 2954-2960. [CrossRef]

59. Datta, A.; Patra, C.; Bharadwaj, H.; Kaur, S.; Dimri, N.; Khajuria, R. Green synthesis of zinc oxide nanoparticles using parthenium hysterophorus leaf extract and evaluation of their antibacterial properties. J. Biotechnol. Biomater. 2017, 7, 271-276. [CrossRef]

60. Abdelkhalek, A.; Sanan-Mishra, N. Differential expression profiles of tomato miRNAs induced by tobacco mosaic virus. J. Agric. Sci. Technol. 2019, 21, 475-485.

61. Huang, J.; Gu, M.; Lai, Z.; Fan, B.; Shi, K.; Zhou, Y.-H.; Yu, J.-Q.; Chen, Z. Functional analysis of the Arabidopsis PAL gene family in plant growth, development, and response to environmental stress. Plant Physiol. 2010, 153, 1526-1538. [CrossRef] 
62. Su, H.; Song, S.; Yan, X.; Fang, L.; Zeng, B.; Zhu, Y. Endogenous salicylic acid shows different correlation with baicalin and baicalein in the medicinal plant Scutellaria baicalensis Georgi subjected to stress and exogenous salicylic acid. PLoS ONE 2018, 13, e0192114. [CrossRef] [PubMed]

63. Vlot, A.C.; Dempsey, D.A.; Klessig, D.F. Salicylic acid, a multifaceted hormone to combat disease. Annu. Rev. Phytopathol. 2009, 47, 177-206. [CrossRef] [PubMed]

64. Dempsey, D.M.A.; Vlot, A.C.; Wildermuth, M.C.; Klessig, D.F. Salicylic acid biosynthesis and metabolism. Arabidopsis. Book Am. Soc. Plant Biol. 2011, 9, e0156. [CrossRef] [PubMed]

65. Pellegrini, L.; Rohfritsch, O.; Fritig, B.; Legrand, M. Phenylalanine ammonia-lyase in tobacco (molecular cloning and gene expression during the hypersensitive reaction to tobacco mosaic virus and the response to a fungal elicitor). Plant Physiol. 1994, 106, 877-886. [CrossRef]

66. Mauch-Mani, B.; Slusarenko, A.J. Production of salicylic acid precursors is a major function of phenylalanine ammonia-lyase in the resistance of Arabidopsis to Peronospora parasitica. Plant Cell 1996, 8, $203-212$. [CrossRef]

67. Dempsey, D.M.A.; Shah, J.; Klessig, D.F. Salicylic acid and disease resistance in plants. Crit. Rev. Plant Sci. 1999, 18, 547-575. [CrossRef]

68. Nawrath, C.; Métraux, J.-P. Salicylic acid induction-deficient mutants of Arabidopsis express PR-2 and PR-5 and accumulate high levels of camalexin after pathogen inoculation. Plant Cell 1999, 11, 1393-1404.

69. Abdelkhalek, A.; Al-Askar, A.A.; Hafez, E. Differential induction and suppression of the potato innate immune system in response to Alfalfa mosaic virus infection. Physiol. Mol. Plant Pathol. 2020, 110, 101485. [CrossRef]

70. Mierziak, J.; Kostyn, K.; Kulma, A. Flavonoids as important molecules of plant interactions with the environment. Molecules 2014, 19, 16240-16265. [CrossRef]

71. Islam, W.; Adnan, M.; Tayyab, M.; Hussain, M.; Islam, S.U. Phyto-metabolites; an impregnable shield against plant viruses. Nat. Prod. Commun. 2018, 13, 1934578X1801300131. [CrossRef]

72. Beckman, C.H. Phenolic-storing cells: Keys to programmed cell death and periderm formation in wilt disease resistance and in general defence responses in plants? Physiol. Mol. Plant Pathol. 2000, 57, 101-110. [CrossRef]

73. Dai, G.H.; Nicole, M.; Andary, C.; Martinez, C.; Bresson, E.; Boher, B.; Daniel, J.-F.; Geiger, J.-P. Flavonoids accumulate in cell walls, middle lamellae and callose-rich papillae during an incompatible interaction betweenXanthomonas campestrispv. malvacearumand cotton. Physiol. Mol. Plant Pathol. 1996, 49, 285-306. [CrossRef]

74. André, C.M.; Schafleitner, R.; Legay, S.; Lefèvre, I.; Aliaga, C.A.A.; Nomberto, G.; Hoffmann, L.; Hausman, J.-F.; Larondelle, Y.; Evers, D. Gene expression changes related to the production of phenolic compounds in potato tubers grown under drought stress. Phytochemistry 2009, 70, 1107-1116. [CrossRef] [PubMed]

75. Kang, J.-H.; McRoberts, J.; Shi, F.; Moreno, J.E.; Jones, A.D.; Howe, G.A. The flavonoid biosynthetic enzyme chalcone isomerase modulates terpenoid production in glandular trichomes of tomato. Plant Physiol. 2014, 164, 1161-1174. [CrossRef] [PubMed]

76. Chamnongpol, S.; Willekens, H.; Moeder, W.; Langebartels, C.; Sandermann, H.; Van Montagu, M.; Inzé, D.; Van Camp, W. Defense activation and enhanced pathogen tolerance induced by $\mathrm{H}_{2} \mathrm{O}_{2}$ in transgenic tobacco. Proc. Natl. Acad. Sci. USA 1998, 95, 5818-5823. [CrossRef] [PubMed]

77. Wu, G.; Shortt, B.J.; Lawrence, E.B.; Leon, J.; Fitzsimmons, K.C.; Levine, E.B.; Raskin, I.; Shah, D.M. Activation of host defense mechanisms by elevated production of H2O2 in transgenic plants. Plant Physiol. 1997, 115, 427-435. [CrossRef]

78. Apel, K.; Hirt, H. Reactive oxygen species: Metabolism, oxidative stress, and signal transduction. Annu. Rev. Plant Biol. 2004, 55, 373-399. [CrossRef]

79. Han, Y.; Luo, Y.; Qin, S.; Xi, L.; Wan, B.; Du, L. Induction of systemic resistance against tobacco mosaic virus by Ningnanmycin in tobacco. Pestic. Biochem. Physiol. 2014, 111, 14-18. [CrossRef]

80. Bindschedler, L.V.; Dewdney, J.; Blee, K.A.; Stone, J.M.; Asai, T.; Plotnikov, J.; Denoux, C.; Hayes, T.; Gerrish, C.; Davies, D.R. Peroxidase-dependent apoplastic oxidative burst in Arabidopsis required for pathogen resistance. Plant J. 2006, 47, 851-863. [CrossRef]

81. Venkatesan, S.; Radjacommare, R.; Nakkeeran, S.; Chandrasekaran, A. Effect of biocontrol agent, plant extracts and safe chemicals in suppression of mungbean yellow mosaic virus (MYMV) in black gram (Vigna mungo). Arch. Phytopathol. Plant Prot. 2010, 43, 59-72. [CrossRef] 
82. Li, Z.; Shi, J.; Hu, D.; Song, B. A polysaccharide found in Dendrobium nobile Lindl stimulates calcium signaling pathway and enhances tobacco defense against TMV. Int. J. Biol. Macromol. 2019, 137, 1286-1297. [CrossRef] [PubMed]

83. Imada, K.; Sakai, S.; Kajihara, H.; Tanaka, S.; Ito, S. Magnesium oxide nanoparticles induce systemic resistance in tomato against bacterial wilt disease. Plant Pathol. 2016, 65, 551-560. [CrossRef]

(C) 2020 by the authors. Licensee MDPI, Basel, Switzerland. This article is an open access article distributed under the terms and conditions of the Creative Commons Attribution (CC BY) license (http://creativecommons.org/licenses/by/4.0/). 